\title{
ENERGY ISSUES IN THE EUROPEAN UNION'S FOREIGN POLICY TOWARDS THE STATES OF THE SOUTH CAUCASUS
}

\begin{abstract}
The Common Foreign and Security Policy is one of these areas of the European Union's activity which arouses wide interest due to the broad spectrum of issues addressed there (i.a. democracy, the rule of law, trade, and issues related to civil, military and energy security) as well as to continuous evolvement of the Policy itself. Thus this area provides an abundance of issues to research on, discuss and assess, while professional diplomats regard it as a vital tool for attaining common goals that are significant from the perspective of a larger whole rather than only that of individual member states. One of such goals is to ensure energy security of the European Union. With this in mind, it is impossible for EU diplomacy to overlook the states of the South Caucasus: Armenia, Azerbaijan and Georgia, both with regard to their energy resources and geographical location. Is the South Caucasus truly the EU's natural direction of improving its energy security? Are these countries able to help the European Union diversify its sources of energy supplies? Finally, are the states of the South Caucasus interested in that? These are only some of the questions the following article should answer.
\end{abstract}

\section{Key words}

European Union, South Caucasus, foreign policy, energy industry, security 
The Common Foreign and Security Policy is one of these areas of the European Union's activity which arouses wide interest due to the broad spectrum of issues addressed there (i.a. democracy, the rule of law, trade, and issues related to civil, military and energy security) as well as to continuous evolvement of the Policy itself. Thus this area provides an abundance of issues to research on, discuss and assess, while professional diplomats regard it as a vital tool for attaining common goals that are significant from the perspective of a larger whole rather than only that of individual member states. One of such goals is to ensure energy security of the European Union. With this in mind, it is impossible for EU diplomacy to overlook the states of the South Caucasus: Armenia, Azerbaijan and Georgia, both with regard to their energy resources and geographical location. Is the South Caucasus truly the EU's natural direction of improving its energy security? Are these countries able to help the European Union diversify its sources of energy supplies? Finally, are the states of the South Caucasus interested in that? These are only some of the questions the following article should answer.

The European Union (the EU) is an organization that is needed. Although populists all over Europe have been recently undermining the veracity of this statement and - though it must be admitted with concern - they have contributed to partial erosion of the principles and values on which this organization is based, still there are such politicians in Europe - and they are the majority - who understand the importance of the European Union for its member states. What is more, they see its potential not only in a strictly economic context but also in issues related to foreign policy in its broader sense. It cannot be concealed that since the conclusion of the Treaty of Lisbon, which regulated detailed powers of EU institutions in this area, much has been done to develop this potential. Legal patterns, economic and trade deregulations, free and common market, solidarity and mutual assistance as well as methods of ensuring security for institutions and citizens are just a few examples of issues which can and should be of interest to third parties and constitute spheres of cooperation with the EU. 
Specific actions of EU institutions in the international arena, particularly in their bilateral contacts with the third states, show such dominant values as democracy, the rule of law as well as civil rights and liberties. However, equally important are economic and trade issues as well as security, including also energy security of EU member states ${ }^{1}$. Certainly, the Treaties mention energy solidarity of the member states - plans for the energy union - however, EU countries are largely dependent on the import of fuels. Unfortunately, this process will be progressive, for instance due to the economic growth. The thing is that this dependency should not be one-sided, that is, Europe should not depend in this respect on Russia exclusively as this country tends to use its fuels policy to put pressure on the third states/organizations. Thus the integrating European countries should do much to ensure diversification of sources and directions of supplies, and therefore their continuity and security. Without this, further rapid economic growth will be impossible, particularly in the eastern part of the EU. One of the geographical directions where energy cooperation of the EU is at least theoretically possible is the South Caucasus: Armenia, Azerbaijan and Georgia.

\section{The Common Foreign and Security Policy of the European Union vs energy issues}

It is no surprise that none of the subjects of international relations operates in this environment without previously establishing their goals and means of achieving the desired results. This is also true for the European Union, which takes all its steps on the basis and within the framework of the Treaties which form it. Thus the key legal provisions regarding this area deserve at least a token examination here.

In the Treaty on European Union (TEU), which is much shorter than the Treaty on the Functioning of the European Union (TFEU), there are no regulations governing energy industry. However, to keep the argumentation precise, art. $3 \mathrm{sec} .1$ should be quoted here: “The Union's aim is to promote peace (...) and the well-being of its peoples", as well as art. $3 \mathrm{sec} .3$, which says that the European Union "shall work for the sustainable development of Europe

1 It is a state in which inhabitants of a given country / organization and all entities operating in its territory / area have access to sufficient energy resources, at a reasonable price, within a given time horizon without any serious risk of interruptions in supplies or without various types of restrictions (see Abolhosseini, Heshmati \& Rashidghalam, 2017, p. 225). 
based on balanced economic growth and price stability" (2016). It is not possible to achieve these goals without guaranteeing stable (in time), predictable (e.g. in political or price contexts) supply of fuels to Europe. Any difficulties and disruptions in this regard may generate (and they certainly will) serious consequences such as economic downturn (economic crisis) or social discontent (when prices of energy grow, this growth is most often financed by taxpayers). Hence it is important that the countries surrounding the European Union, particularly these which have fuels or can be transit states, are free of conflicts and have stable governments, preferably democratic ones and of friendly attitude towards Europe. This is among the reasons why the EU pays particular attention to its values also in the international dimension.

Art. 32 of TEU is also interesting here: "Member States shall consult one another within the European Council and the Council on any matter of foreign and security policy of general interest in order to determine a common approach. Before undertaking any action on the international scene or entering into any commitment which could affect the Union's interests, each Member State shall consult the others (...). Member States shall show mutual solidarity”. Such approach to the issue results in the fact that in questions of broadly understood energy security, which each state treats as strategically important to itself, there is no absolute need to obtain consent, or even tacit consent of other EU members for any actions. It is therefore no surprise there are situations in which individual member states take individualized actions in this respect without looking at their allies. There is no need to look far: the issue of building Nord Stream by a Russian-German consortium when Poland and, among others, Sweden were opposed to the project is a perfect example here.

More information in this regard is in the second Treaty mentioned above. We learn from it that energy is one of the competences shared between the EU and the member states (art. $4 \mathrm{sec} .2$ (i)) and that trans-European energy networks are being developed to support the economic growth of the whole European Union (art. 170 sec. 1). Moreover, "in the context of the establishment and functioning of the internal market and with regard for the need to preserve and improve the environment, Union policy on energy shall aim, in a spirit of solidarity between Member States, to: a) ensure the functioning of the energy market; b) ensure security of energy supply in the Union; c) promote energy efficiency and energy saving and the development of new and renewable forms of energy; d) promote the interconnection of energy networks" (TFEU, art. 194 sec. 1). Importantly, the member states have the right to "determine the conditions for exploiting its energy resources, its choice between different energy sources and the general 
structure of its energy supply" (art. $194 \mathrm{sec} .2$ par. 2). The variety of strategic interests of states in the field of energy and power industry, structure of supply, sources of energy production, directions and types of fuels supplies are factors that make it extremely difficult to overcome individualistic thinking in the EU.

The document which to some extent specifies these very general treaty regulations is A Global Strategy for the European Union's Foreign and Security Policy. Shared Vision, Common Action: A Stronger Europe (2016). It was indicated there that lack of energy security is a threat to the citizens and the territory of EU states (p. 19), hence the intensification of actions in the field of energy, including the creation of the Energy Union in the future, through which, at least in theory, it will be possible to "diversify its energy sources, routes and suppliers, particularly in the gas domain ${ }^{2}$, and through our energy diplomacy, we will strengthen relations worldwide with reliable energy-producing and transit countries, and support the establishment of infrastructure to allow diversified sources to reach European markets ${ }^{3 "}$ (p. 22). Finally, in the Strategy it was also declared that it is in the EU's interest "to invest in the resilience of states and societies to the east stretching into Central Asia, and south down to Central Africa" (p. 23) ${ }^{4}$. The names Armenia, Azerbaijan, or the South Caucasus do not appear in the Strategy at all, and Georgia (see more in Gogolashvili, 2017) - barely once, as an example of transformation success. Nevertheless, this is not an affront to them as the said document remains at a high level of geographical generality (it uses rather the names of continents) ${ }^{5}$.

Finally, going from general to particular, it should be pointed out that in 2006 the EU issued the Green Book titled "Energy Policy for Europe" in order to create a certain catalogue of energy regulations both for itself and for its neighbors (European Commission, 2007). The authors of this document intended to Europeanize the energy market, which was to be understood as an intention to develop it according to common and clearly defined standards (World Experience for Georgia, 2015, pp. 9-40) through inviting not only EU members but

\footnotetext{
2 This regulation is directly aimed at Russia.

3 These activities include EU diplomatic contacts with countries such as states of the South Caucasus.

4 Importantly, this is not just the feeling of EU politicians and officials. The citizens (81\%) also see the fact that the broadly understood development aid for developing countries is in the interest of the organization and the member states (Special Eurobarometer 476,2018 , p. 24).

5 In the European Security Strategy of 2003, the antecedent of the document discussed here, the region was given more attention.
} 
also third parties to participate in it. In this way, EU energy policy (including security issues) became part of the EU's foreign policy. As Tamar Pataraia rightly pointed out, "the core aim of the EU's energy security strategy is [now] to diversify the supply routes for energy resources, which would protect the European energy market from geopolitical risks" $(2015$, p. 5).

\section{The European Union's bilateral relation with the states of the South Caucasus}

\subsection{The European Union's perspective}

When the states of the South Caucasus again proclaimed their sovereignty in 1991, the then existing European Economic Community barely noticed that fact. First of all, this resulted from the final stage of negotiations on the Maastricht Treaty which was to found the European Union. Secondly, the political and economic situation (dissolution of the Eastern Bloc) on the eastern border of integrating Europe was then extremely dynamic and almost completely attracted the attention of European politicians. The third factor conditioning Europe's lack of stronger interest in the Caucasus was the war in the immediate neighborhood of the EU - the Balkans, Europe's soft underbelly. Fourthly and finally, the South Caucasus was a remote, not only in the geographical sense, region that remained - in the way of thinking of many politicians - the Russian sphere of influence, which was turbulent and strongly conflicted internally (Pataraia, 2015, p. 1). There was also no relevant knowledge about the region and its identity (Gevorgyan, 2015, p. 92). Hence, it is not surprising that the beginnings of bilateral relations were extraordinarily conservative, and the activities focused on the issues of both internal security of the region, troubled by conflicts and separatisms, and of external security, influenced by the eternal rivalry in the Caucasus between the regional powers: Russia, Iran and Turkey (Nuriyev, 2007, p. 1).

Today, the situation looks different and the EU's presence in the region is more visible, as evidenced by the EU Delegations in its capital cities. It is natural that the EU's presence and activity is different in each of these states. All these countries benefit from the European Neighbourhood Policy $(\mathrm{ENP})^{6}$, the Eastern Part-

6 Its implementation is important for both sides: thanks to it, the European Union gains a real tool of influence, and the states of the South Caucasus gain financial resources, know-how and closer ties with Europe. 
nership (EaP), the "Black Sea Synergy" initiative, and the Energy Charter Treaty?. It is the intention of EU politicians that these policies, initiatives and projects are to contribute to the democratization of beneficiary states and the marketization of their economies; it is also an opportunity to strengthen mutual relations, not only at the highest level, but also at the social and cultural level.

It was resolved that the Energy Community (established in 2006) ${ }^{8}$ - an organization with an extensive set of regulations regarding i.a. gas, electricity, security of supply, various types of fuels, energy efficiency, renewable energy sources and competitiveness - is to extend the EU energy market beyond the borders of the EU in order to stabilize the market, guarantee the security and timeliness of fuels supplies, thus contributing to sustainable economic and social development (Green Alternative, 2015, p. 11). Although they could, Armenia and Azerbaijan have not joined this initiative yet, and Georgia, as the model of transformation in the region, did so only on 1 July 2017. This was mainly due to delays in the democratization of public life in these countries, as well as the reluctance to accept and implement detailed, pro-ecological and sometimes even undesirable EU regulations (Pataraia, 2015, p. 6).

The EU's growing interest in the region should not come as a surprise. This is a necessity as it is widely known that Azerbaijan has huge deposits of natural gas, and the region may prove extremely valuable when it comes to the transit of fuels from the Caspian region, which is a serious alternative to gas and oil from Russia and states of the Persian Gulf. Diversification of the direction of supplies is one thing, but growing energy needs should also be satisfied because "[t]he EU will rely on external imports for more than $70 \%$ of its energy supply by 2030 . The 2006 Russia-Ukraine gas crisis prompted broad consensus among the EU-27 on the need to diversify supply away from Russia, inter alia, through a Southern Corridor (...)" (European Commission, 2011). Stabilizing the situation in the region may also become an opportunity for European enterprises, particularly from the petrochemical and gas sector, to invest in transmission and processing infrastructure projects in these countries (Nuriyev, 2007, p. 2).

It would be a mistake to assume that the abovementioned activities of the European Union towards Armenia, Azerbaijan and Georgia have fundamentally influenced EU policy towards these countries. Nuriyev (2007, p. 3) indicates that

${ }^{7}$ In the last case, which comprehensively addresses energy issues, the states of the South Caucasus quickly showed interest in cooperation with the EU: Georgia joined it in 1995, Azerbaijan in 1998, and Armenia followed.

${ }^{8}$ See https://www.energy-community.org/ 
"[t]he EU still lacks a clear institutional force driving the formulation of a strategic vision for the South Caucasus", and Amanda Paul states that "the EU still lacks a clear strategic vision and coherent policies for the region" (2016, p. 13) and that "a one-size-fits-all approach does not work and that the EU needs to develop more tailor-made relationships, with a stronger focus on bilateral ties, and moving away from a 'one-menu-for-all' to an approach based on clear objectives and benchmarks; tangible benefits and with clear roadmaps" (2015, p. 83).

\subsection{Bilateral relations with the EU - perspective of the states of the South Caucasus}

The 1990s was a period in which the states in question were forced to rebuild their infrastructure, including the energy one, destroyed as a result of political instability. They also had to determine the political and economic circle which they wanted to join. Each of the states of the South Caucasus uses a different strategy for talks with the EU as the organization has different importance for them and they have different expectations towards it. Suffice it to say that Georgia is endeavouring to move closer to the EU, Azerbaijan is giving priority to a phased approach and Armenia currently does not view EU membership as a vital element of its foreign policy. The South Caucasian states have not yet become concrete candidates for EU membership, nor do they seem to have such prospects in the foreseeable future" (Nuriyev, 2007, p. 2).

What is more, geopolitical reality does not make it easier for these states to follow a stable and predictable foreign policy towards integrating Europe. This situation was characterized plainly by Leila Alieva (2006), who said that the relations "are best described by the contradiction between the 'identity and geography', when states of the Caucasus look at the West tying their aspirations with integration, while the West is evidently not ready in bringing them closer as they did in case of Central and East European states and Baltic republics [or even the Balkans]" (p. 5). Certain changes in the way Azerbaijan and Georgia are perceived and treated by European politicians and officials result from putting the transportation infrastructure for energy resources (BTC and BTE) into use, which allowed the introduction of Azerbaijani fuels to the free market, including Europe, thus putting an end to Russian unwavering monopoly in this regard (Kusznir, 2011, p. 4). 


\section{Armenia}

The European Union established framework of its bilateral relations with Armenia in 1999 by entering with this state into the Partnership and Cooperation Agreement (PCA) (in force since 1999). Next, Armenia became a part of the European Neighbourhood Policy and Eastern Partnership Program. The final step, whose aim was to formalize mutual contacts, was the Association Agreement. Despite difficult talks and different pace of internal reforms in the country's individual sectors ${ }^{9}$, the negotiations were successful (July 2013). The situation was similar in the case of the Deep and Comprehensive Trade Area (DCFTA), a part of the PCA, which was to remove barriers and restrictions on bilateral trade. However, when the documents were ready to be signed at the highest political level (during the Vilnius summit in 2013), Armenia made a turn in its foreign policy and on 3 September 2013 announced its accession to the Russia-controlled Eurasian Economic Union ${ }^{10}$, justifying this step on the grounds of its own security ${ }^{11}$. This decision caused consternation in Brussels - the words of the Armenian president about the will to continue the state's dialogue with the EU were not met with understanding - and seriously strained further bilateral relations for some time. This was not changed either by subsequent joint declarations or by the agreement on visa facilitation for Azeri travelling to the EU, nor by next subsidies for this state received from EU funds and programs. It was only thanks to the Comprehensive and Enhanced Partnership Agreement (CEPA), initiated on 27 March 2017, that bilateral contacts were re-established, and since that day Yerevan's new political and economic commitments have been taken into account in the EU-Armenia bilateral relations.

9 In its regular report in 2013, the European Commission highlighted the satisfactory progress of reforms in sectoral policies; however, insufficient with regard to human rights, democracy and the rule of law, macroeconomics, combating poverty, and social cohesion.

10 Thanks to this, Armenia has guaranteed gas supplies; Russians also ensure smooth functioning of the Metsamor nuclear power plant and utilize radioactive waste generated as a result. The EU would like its closure or at least its thorough modernization (security and environmental reasons). According to Yerevan, the closure is not possible so far as it provides about $1 / 3$ of the electricity generated in Armenia, and there are no funds in the state's budget for its modernization.

11 As a tool of political pressure, Russia raised gas prices for the Armenian recipient; in addition, Russia signed a major contract for the supply of weapons to Azerbaijan, the enemy of Armenia. 
It should be emphasized that the close, though somewhat forced, relations between Armenia and Russia, the conflict with Azerbaijan about NagornoKarabakh and the lack of official relations with Turkey (the consequences of what happened to Armenians in Turkey in the early 20th century) resulted in the fact that Armenia was not included in the South Caucasus transit infrastructure of energy resources from the Caspian Sea to the West. Armenia has found itself in isolation, and its territory is not used for the transit of fuels from Central Asia, and thus the country does not profit from this process ${ }^{12}$. Although the Armenian energy sector was not covered by the common regulations of the Eurasian Economic Union, which could be the basis for talks with the European Union in this regard, the recent agreement for the supply of Russian gas by Gazprom, concluded shortly after the rejection of the association agreement with the EU, is a serious obstacle here. It is enough to mention that the contract with the Russian state concern "grants Gazprom a monopoly to operate pipelines until 2043 and does not allow Armenia to make, annul or change laws and decision or issue decrees until 31 December 2043" (Kostanyan \& Giragosian, 2017, p. 13). This situation significantly limits the possibilities of EU-Armenian energy cooperation, or even makes this cooperation impossible.

Bilateral trade is not an issue which, to put it politely, brings a flush of excitement to the cheeks of EU officials. The figures of the Directorate General for Trade of the European Commission for 2017 show that the turnover amounted to 1.102 billion euros: the EU imported goods for 384 million euros, and exported for 718 million euros. The share of trade with Armenia was below $0.1 \%$ of the global annual trade turnover of the European Union and thus Armenia was ranked only on 109th among the organization's key trading partners. This result cannot be considered satisfactory since the potential of the relationships in question is certainly bigger. For Armenia, however, the EU is the second most important trade partner after Russia (DG Trade 2018a, pp. 2-10).

\section{Azerbaijan}

At the time of declaring its independence (1991) Azerbaijan decided to adopt a balanced strategy in international politics, which should be understood as the willingness to maintain balance between Europe and Asia. The key factors in

12 Yerevan is partially supplied with gas also through a new gas pipeline from Iran, but this infrastructure does not allow transit of gas outside Armenia. 
this respect were its geographical location, natural resources and cultural heritage. Baku makes a judicious use of these advantages, in particular as an exporter of fuels and the only possible route of fuels transit from Central Asia to Europe that makes it possible to bypass both Iran and Russia (the so-called Southern Gas Corridor). Thus Azerbaijan also maximizes its room for manoeuvre as far as Russia is concerned, gains certain benefits from the EU, and simultaneously refuses to accept any attempts to impose Western norms and standards in its public life, staunchly defending its priorities in this regard (Jarosiewicz, 2014, p. 1; Paul, 2016, p. 8).

The legal grounds for relations with the EU is the Partnership and Cooperation Agreement (PCA), signed in 1996 and in force since June 1999. Azerbaijan was also included in the ENP in 2004 and in the Eastern Partnership in 2009. However, the reports of EU institutions on Baku's progress on the road to democratisation and marketization clearly point out that the state governments do not give much consideration to political and social aspects of bilateral relations (Hale, 2012, p. 4). Furthermore, international observers notice the continuously worsening situation of citizens and non-state subjects, especially with regard to rights and freedoms. Azerbaijan joined the ENP hoping for liberalisation of visa regulations for its citizens (which did happen on 1 September 2014) and strengthening economic cooperation with the EU (which was partially successful). The annexation of Crimea by Russia gave rise to resentment that the EU had never taken such a decisive stance on Azerbaijan's territorial integrity (the issue of the Nagorno-Karabakh conflict with Armenia). This may be the factor underlying demonstrations of growing antipathy towards political and legal aspects of relations with the European Union - the EU would like to initiate the process of departing from authoritarian rule and state control over public life, to which Baku responds with an increasingly decisive "No" (Tartes, 2015, p. 28; Zasztowt, 2015, pp. 1-2).

The year 2006 saw the conclusion of the Memorandum of Understanding on Strategic Partnership in the field of Energy, as well as the Joint Declaration on the Southern Gas Corridor; Azerbaijan also emphasizes continuously its readiness to play a significant role in the EU's energy security strategy ${ }^{13}$. With a view to fostering closer mutual relations, the talks on Association Agreement were initiated, but in 2014 they died a natural death as a result of the crisis in Ukraine and Russian actions on Ukrainian territory. Parallel negotiations on the DCFTA

13 European energy companies, such as BP, Total and Statoil, are willing to invest there. 
could not be initiated as Azerbaijan still is not a member of the WTO, which constitutes a prerequisite for this kind of agreement. However, the spring of 2016 marked the start of negotiations on the replacement of the PCA with a new agreement - the Strategic Partnership Agreement (SPA), expanding the areas of bilateral cooperation. The talks are difficult, and the EU needs to balance appropriately economic interests (energy) and values (pressure on Baku with regard to democratisation of public life), which by no means will be an easy task (Kobzova \& Alieva, 2012, p. 7).

It seems self-evident that even in the medium term it will be impossible to entirely replace the Russian direction of gas supply to the EU. However, the Azerbaijan direction, perhaps also together with supplies from Central Asia, certainly can be a significant source of diversification and increased energy security of EU states because, as Baku has already proven, Azerbaijan is not afraid of Russian pressure in this matter (European Parliament, 2017, p. 26). With the support from the US and the EU, in cooperation with Turkey and Georgia (and at the same time excluding Armenia from any transit projects), the Baku government managed to create an extensive network of oil pipelines: Baku-Tbilisi-Ceyhan (BTC) $)^{14}$ and Baku-Supsa, as well as gas pipelines: the South Caucasus Pipeline Baku-Tbilisi-Erzurum (BTE) (Abolhosseini, Heshmati \& Rashidghalam, 2017, p. 232; European Parliament, 2017, p. 26; Gasimli, 2015, p. 64; Gevorgyan, 2015, p. 99; Khachatryan, 2015, p. 11; Zasztowt, 2015, pp. 2-3 ${ }^{15}$. In September 2011 the multilateral agreement on the Trans-Caspian Gas Pipeline was signed, in accordance to which minimum 10\% of Azerbaijani gas from Shah Deniz 2 field is to be transferred to the EU via the extension of the BTE with the gas pipelines TANAP (Trans Anatolia Natural Gas Pipeline) and TAP (Trans Adriatic Pipeline) from Turkey to Italy, Greece and Albania ${ }^{16}$. Besides, one must not forget the ambitious EU plan - the Nabucco project. Another interesting project is the Trans-Caspian Gas Pipeline, connecting Kazakhstan and Turkmenistan

14 BTC "runs close to the conflict zones where the separatist regimes and various rebel groups, including the Kurdistan Workers' Party, have threatened to target the regional pipeline network if their demands are not met. This risk could pose a potentially destabilizing effect on European markets. (...) The necessity of increasing the EU's political and economic investment in the stability and security of the region will inevitably grow stronger" (Nuriyev, 2007, p. 8).

${ }^{15}$ Interestingly, Georgia also uses this infrastructure as a consumer of Azerbaijani gas, which only tightens their relations.

${ }_{16}$ The ultimate shape of this project is not yet known, currently being a subject of in-depth analyses. 
with Azerbaijan and Georgia, and further with Turkey and the EU. Despite Moscow's attempts to block the project ${ }^{17}$, and Russia signing alternative agreements with both these states, this project is too important also for them to yield to Moscow's pressure.

Trade contacts with Azerbaijan - and it should not be a great surprise considering the natural resources and geographical location of this state - are very important for the EU. The data collected for 2017 reveal that the total value of bilateral trade amounted to 11.122 billion euros: 9.41 billion euros of the EU's import and 1.711 billion euros of its export. The distinct deficit of turnover on the EU side is clearly noticeable. Due to these results, Azerbaijan was classified 44th in the ranking of the EU's trade partners, with its participation exceeding $0.3 \%$ of the EU's total trade. In turn, the EU is decidedly the most important trade partner of Azerbaijan (with its share over 35.5\%). To specify, it should be pointed here that the key element of the EU's import from Azerbaijan are fuels and minerals: 9.234 billion euros (Csabay, 2017, pp. 3-15; DG Trade 2018b, pp. 2-10). Thus if all the projects of construction and expansion of transit infrastructure came to fruition, the importance of Azerbaijan-EU trade relations would certainly increase.

\section{Georgia}

In 1999 the parties signed the PCA, which significantly expanded and formalized the bilateral relations. Georgia adopted a strongly pro-Western direction in its foreign policy in 2003, after the Rose Revolution. Despite various turbulences of internal (changes in political leadership) and external character (the cost of the conflict with Russia in 2008 for Georgia was the de facto loss of Abkhazia and South Ossetia ${ }^{18}$ ), this direction is basically still maintained. Today Geor-

17 Only recently, on 12 August 2018 after 22 years of negotiations, Azerbaijan, Iran, Kazakhstan, Russia and Turkmenistan signed an agreement regulating the legal status of the Caspian Sea. It is the first yet significant step on the road to unblocking energy projects, such as the trans-Caspian pipeline beneficial for the EU. At the same time, signing a document guarantees nothing: what is needed is its ratification by all parties. Furthermore, its provisions are not entirely precise, which may cause in the future further disputes between the interested parties. (Legucka, 2018, pp. 1-3).

18 In reality it was Georgia that suffered the physical, territorial loss; however, if the Russian operation had been on a larger scale and had not met with noticeable diplomatic resistance from the West, it would have succeeded in making it impossible for Azerbaijan and further gas and oil producers of the Caspian Sea region to transport 
gia is considered a model of political, economic and social reforms for other states in the region; it also fully benefits from the ENP and EaP. After the 2008 conflict the EU established an observatory mission at the Georgian-Russian border (the territory annexed by Russia). Since June 2014 the Association Agreement has been in force, together with the DCFTA part concerning trade, and the Georgian citizens benefit from facilitation of entry to the Schengen Area (Sammut, 2016, p. 2). Lacking its own fuels and unwilling to obtain them from Russia, Georgia purchases them in the open market from Azerbaijan and thus indirectly from Turkmenistan and Kazakhstan as well.

The figures concerning bilateral trade between the EU and Georgia are not particularly impressive. The total trade turnover for 2017 amounted to 2.658 billion euro: 668 million euros of EU import and 1.990 billion euros of EU export. Thus the EU has positive trade balance with the second economy of the region; however, this does not change the fact that the EU's balance with the whole region is distinctly negative. The $0.1 \%$ share of Georgia in the EU's global trade gave it ultimately the 73rd place among the EU's trade partners. In turn, the EU is the most important trade partner of Georgia, with $26.6 \%$ share in the latter's foreign trade. The key goods imported to the EU are raw materials (316 million euro) and petrochemical products (70 million euro) (European Commission Directorate-General for Trade, 2018c, pp. 2-10).

\section{Concluding remarks}

As mentioned above, the EU took notice of new independent states that emerged in the South Caucasus in the 1990s. Following tradition, it established diplomatic and trade contacts with them. However, despite mutual relations that have lasted for over a quarter of the century, the organization and its operations still remain something new and unknown in comparison with the traditional regional powers that have been present there for centuries, such as Russia ${ }^{19}$, Iran

fuels in the Western direction. Thus Russia would have managed to ensure its continued position of a monopolist in this aspect; however, it was possible to avoid such situation (Abolhosseini et al, 2017, p. 234).

19 Amanda Paul (2016) ventured an interesting comment on Russia's activity in the South Caucasus region: "Russia remains the most dominant actor in the South Caucasus. Moscow simultaneously plays the role of peacemaker, troublemaker, arms supplier, regional policeman, economic hegemon, and protector of 'traditional values'” (p. 11). Anyway, the EU's entire geopolitical thinking about the region is fraught with worries about 
and Turkey, which also promote their own interests there (Boonstra \& Delcour, 2015, p. 1). This does not expedite the EU's actions nor does it facilitate spreading positive influence in the region. Furthermore, for a variety of reasons the region is torn and divided, and Armenia, Azerbaijan and Georgia represent entirely different, sometimes even opposite approaches to the issue of becoming a part of international politics (Paul, 2015, p. 79). This is not good for the region; cooperation and regional interaction would certainly be more beneficial for these states (van den Boom, 2017, p. 6), particularly considering that e.g. the EU willingly uses the "region" category in its foreign policy, and co-operating Caucasus states would be a more serious and important partner for any third party operating there, including integrated Europe.

With energy security in mind, EU politicians cannot afford ignoring a region such as the South Caucasus, leaving it entirely in the hands of those powers that for centuries have promoted their interests there, fighting a turf war. As Leila Alieva (2006) points out, "Caucasus is a 'bridge' and 'transit area' not only of the material goods, but is a conductor of the political and cultural influences" (p. 17). In turn Dogan Girkin (2016) argues that " $[t]$ he Caucasus region contains the potential to have a significant presence in the global energy market as a key player" (p. 25). Good relations with Azerbaijan would allow energy-hungry Europe to use the energy resources located there; friendly relations with Armenia and Georgia, supported by difficult democratic reforms in these states, are necessary if modern infrastructure ${ }^{20}$ is to be built there and used for transit of fuels from the Caspian Sea region (Turkmenistan and Kazakhstan ${ }^{21}$ ). Both sides would profit from this - Europe would gain alternative supplies of fuels, which would reduce its dependence on Russia in this aspect, while the countries

Moscow's reaction to the EU's endeavours. Europe does not want to isolate either Russia or Iran with regard to using commercial opportunities that have appeared in the Caspian Sea region, which in turn is what the US would like very much (Nuriyev, 2007, p. 22).

20 The SCEF publication demonstrates that besides traditional challenges with regard to energy diversification in the Southern Caucasus region, what should be also considered is "environmental damage that is caused by the inefficient use of energy resources" (2014, pp. 5-6).

${ }^{21}$ Both states are naturally interested in selling their gas to Europe. They expect, however, that Europe will be the one to bear the burden of reaching an accord with Russia regarding the agreement to build necessary infrastructure, and that it will cover the costs of such construction. However, the governments of these states realize that the EU lacks resources to finance such project and to challenge Moscow in the near future (see Genté, p. 75). 
of the South Caucasus would gain means to modernize the states and societies, which would also positively influence stability of the whole region (Efe, 2012, p. 196). However, for this to happen, the European Union must find more courage and determination, start to speak with one voice, and use properly formulated and tailored negotiation strategies in relations with individual states. Otherwise it will be difficult to expect positive changes in energy security of Europe.

\section{REFERENCES}

Abolhosseini, S., Heshmati, A., \& Rashidghalam, M. (2017). Energy security and competition over energy resources in Iran and Caucasus region. AIMS Energy, 5(2).

Alieva, L. (2006). EU and South Caucasus. CAP Discussion Paper, 12.

Boonstra, J., \& Delcour, L. (2015). A broken region: evaluating EU policies in South Caucasus - Analysis. Retrieved from http://fride.org/descarga/29.01.2015_EurasiaReview_US_JB.pdf

Csabay, J. (2017). EU Policy towards Azerbaijan: Coherence, Policy Shifts and the Upcoming Agreement. STRATPOL Policy Papers, 14 November 2017.

Efe, H. (2012). Foreign Policy of the European Union Towards the South Caucasus. International Journal of Business and Social Science, 3(17).

European Commission. (2007). Communication from the Commission to the European Council and the European Parliament of 10 January 2007, "An energy policy for Europe" [COM(2007) 1 final - Not published in the Official Journal]. Retrieved from https://eur-lex.europa.eu/legal-content/EN/TXT/HTML/?uri=LEGISSUM:127067\& from $=\mathrm{EN}$

European Commission. (2011). Communication from the Commission to the European Parliament, the Council, the European Economic and Social Committee and the Committee of the Regions on security of energy supply and international cooperation - "The EU Energy Policy: Engaging with Partners beyond Our Borders". Retrieved from https:/eur-lex.europa.eu/legal-content/EN/TXT/HTML/?uri=CEL EX:52011DC0539\&from $=$ en

European Commission - Directorate-General for Trade. (2018a). Armenia. Retrieved from http://trade.ec.europa.eu/doclib/docs/2006/september/tradoc_113345.pdf

European Commission - Directorate-General for Trade. (2018b). Azerbaijan. Retrieved from http://trade.ec.europa.eu/doclib/docs/2006/september/tradoc_113347.pdf

European Commission - Directorate-General for Trade. (2018c). Georgia. Retrieved from http://trade.ec.europa.eu/doclib/docs/2006/september/tradoc_113383.pdf

European Parliament. (2017). EU relations with Armenia and Azerbaijan. Retrieved from http://www.europarl.europa.eu/cmsdata/133502/EU\%20relations\%20with\%20 Armenia\%20and\%20Azerbaijan.pdf 
European Union. (2016). Shared Vision, Common Action: A Stronger Europe. A Global Strategy for the European Union's Foreign And Security Policy. Retrieved from: http:// europa.eu/globalstrategy/en

Gasimli, V. (2015). Trade, economic and energy cooperation: challenges for a fragmented region. In The South Caucasus. Between integration and fragmentation. Retrieved from http://www.epc.eu/documents/uploads/pub_5598_article_2_-_amanda_paul_-_ eu.pdf?doc_id=1631

Genté, R. (2013). Energy Competition in the South Caucasus: Driver of Stability or Instability? In E. M. Felberbauer \& F. Labarre (eds.), De-conflicting Protracted Conflicts in the South Caucasus: The Role of the EU and NATO. Vienna: National Defence Academy and Bureau for Security Policy at the Austrian Ministry of Defence.

Gevorgyan, N. (2015). The EU's Strategic Interests in the South Caucasus: from a Bystander to Perceived Interests. Armenian Journal of Political Science, 2(3).

Girgin, D. (2016). Analyzing of the Geopolitical Energy Confrontation in the Caucasus: Role of Iran, After Sanctions Were Lifted. International Journal of Humanities and Social Science Invention, 5(6).

Gogolashvili, K. (2017). Georgia-EU Relations and Future Perspectives. Tbilisi: Georgian Center for Security and Development.

Green Alternative. (2015). Georgia and European Energy Community. The Challenges of EU Integration. Retrieved from https:/greenalt.org/wp-content/uploads/2015/06/ Georgia_and_European_Energy_Community.pdf

Hale, J. (2012). EU relations with Azerbaijan: More for Less? Retrieved from https://www. opensocietyfoundations.org/sites/default/files/eu-relations-azerbaijan-20120606.pdf Jarosiewicz, A. (2014). Azerbaijan - a growing problem for the West. OSW-CES Commentary, 15.09.2014.

Khachatryan, D. (2015). The EU's Niche in the New South Caucasus: Old Partners, New Challenges. Retrieved from http://tesev.org.tr/wp-content/uploads/2015/11/ The_EUs_Niche_In_The_South_Caucasus_Old_Partners_New_Challenges.pdf

Kobzova, J., \& Alieva, L. (2012). The EU and Azerbaijan: Beyond the Oil. ECFR Policy Memo, 22.05.2012.

Kostanyan, H., \& Giragosian, R. (2017). EU-Armenian Relations: Charting a fresh course. CEPS Research Report, 14.

Kusznir, J. (2011). The Nabucco Gas Pipeline Project and its Impact on EU Energy Policy in the South Caucasus. Caucasus Analytical Digest, 33.

Legucka, A. (2018). Uregulowanie statusu Morza Kaspijskiego. Biuletyn PISM, 116(1689). Nuriyev, E. (2007). EU Policy in the South Caucasus. A view from Azerbaijan. CEPS Working Document, 272.

Pataraia, T. (2015). Energy transit and security imbalance in South Caucasus. The road between Russia and the European Union. Retrieved from: http://ge.boell.org/sites/ default/files/uploads/2015/03/energy_eng-final_1.pdf 
Paul, A. (2015). The EU and the South Caucasus - Time for a Stocktake. In The South Caucasus. Between integration and fragmentation. Retrieved from http://www.epc.eu/ documents/uploads/pub_5598_article_2_-_amanda_paul_-_eu.pdf?doc_id=1631

Paul, A. (2016). The EU and the South Caucasus 25 Years Since Independence. Retrieved from https:/eu.boell.org/sites/default/files/uploads/2016/11/the_eu_and_the_south_ caucasus_25_years_since_independence_0.pdf

Sammut, D. (2016). Georgia and the EU - maintaining the momentum. European Policy Centre. Retrieved from https://www.epc.eu/pub_details.php?cat_id=4\&pub_id=6796 South Caucasus Energy Forum (SCEF). (2014). Energy Diversification Trends in the South Caucasus and the Neighborhood. Tbilisi: Konrad Adenauer Stiftung.

Special Eurobarometer 476. (2018). EU citizens and development cooperation. Retrieved from http://ec.europa.eu/commfrontoffice/publicopinion/index.cfm/Survey/getSurveyDetail/instruments/SPECIAL/surveyKy/2202

Tartes, A. (2015). The Limited Influence of the European Union in Armenia and Azerbaijan: A Domestic Explanation. EU Diplomacy Paper, 9.

Treaty on European Union TEU (Consolidated version 2016). OJ C 202, 7.06.2016.

Treaty on the Functioning of the European Union TFEU (Consolidated version 2016). OJ C 202, 7.06.2016.

Van den Boom, B. (2017). EU Region-Building in the Neighbourhood The Eastern Partnership's Contribution in the South Caucasus. EU Diplomacy Paper, 4.

World Experience for Georgia (WEG). (2015). Georgian Energy Sector In The Context Of EU Association. Tbilisi: Konrad Adenauer Stiftung.

Zasztowt, K. (2015). Azerbaijan and the EU: Prospects for Partnership Beyond Energy. PISM Strategic File, 2(65). 